Cite as: Jones, K. and Sinkinson, A. (1999), A Critical Analysis of OFSTED Judgements of the Quality of Secondary Mathematics Initial Teacher Education Courses. Paper presented at the Symposium on 'Critical Issues in Mathematics Initial Teacher Education' at the British Educational Research Association Annual Conference 1999 (BERA1999), The University of Sussex, Brighton, 2-5 September 1999.

\title{
A Critical Analysis of Ofsted Judgements of the Quality of Secondary Mathematics Initial Teacher Education Courses
}

\author{
Keith Jones, University of Southampton, and \\ Anne Sinkinson, Homerton College, Cambridge
}

\begin{abstract}
The quality of initial teacher education courses has been the subject of adverse comment and media speculation for some time. During 1996/7, Ofsted began a comprehensive round of inspections of secondary initial teacher education providers using an extensive framework of inspection. This paper reports the results of the first round of inspection of secondary mathematics PGCE providers. Almost three-quarters were judged to be good or better. In examining the inspection reports from a critical perspective, this paper focuses on the level of consistency in the judgements made in the published inspection reports. The analysis demonstrates that there is considerable variation in the reports, in terms of word length, how particular criteria seem to be applied, and how judgments are expressed. With the complexity of the framework for inspection, it is impossible, given the current model of inspection report, to properly distinguish between consistency of application and the loading given to any particular criterion. Attention to the transparency of the inspection process is crucial if there is to be confidence in the inspection system.
\end{abstract}

\section{Introduction}

For more than ten years, courses of initial teacher education in England and Wales have been subjected to adverse comment and media speculation. Lawlor (1990), for example, suggested that UK higher education should cease to have anything to do with the training of teachers, charging that, "despite the intentions of government reforms, the training discourages good candidates from entering the profession and undermines the standards of those who do" (p7). From a similar position, O'Keeffe (1990) attacked UK teacher educators for their "partially successful attempt to infantilise the education system, .. one of the most shameful scandals of modern British public life" (p22). This form of wholesale condemnation of teacher education continued through the 1990s with, for instance, Lord Rannoch stating in the House of Lords in July 1996 that there is "much that one can criticise about these courses [of initial teacher education] .... controlled by a large, powerful, vicious and insular education establishment." (Rannoch 1996). More recently the argument has been promulgated that if standards in schools were too low it was because the teachers were not trained properly. For example, the Chief Inspector of Schools stated at a seminar organised by the Universities Council for the Education of Teachers in February 1997 that "I think that standards are too low in too many schools must 
reflect on what's happening by way of training the teachers" (recorded verbatim in Convey 1997 p 30).

During the early 1990s, Ofsted ${ }^{1}$ data certainly pointed to things not being altogether well in secondary mathematics initial teacher education. In 1991/2 Ofsted carried out a study of one-third of secondary PGCE courses provided by Universities (at the time Universities provided less than half of such PGCE places, the bulk of courses were in Polytechnics and Colleges). The study found that secondary mathematics was "the only subject [out of 10 inspected] in which none of the work seen was better than satisfactory" (Ofsted 1993a p9). Problems of similar nature were found in a 1992 Ofsted survey of newly qualified teachers observed towards the end of their first year of teaching. In 32 mathematics lessons observed, none were graded very good, while about $20 \%$ were graded unsatisfactory (Ofsted 1993b p18). Nevertheless, $80 \%$ were graded satisfactory or good, a proportion that appears to be little different from that of more experienced teachers of mathematics at the time for whom up to a third of lessons were judged unsatisfactory or poor (Ofsted 1992). Despite this, such data on newly qualified teachers was seen to be directly related to the quality of the training they had received, although the Ofsted survey does report that most of the unsatisfactory new teachers were "in poor schools where the overall standards of teaching and learning were generally poor" (ibid p23). As such these newly qualified teachers were found to be hampered by an absence of schemes of work, inherent difficulties with the class being observed, and poor provision of resources. While such data, both about some of the training courses and about the quality of newly qualified teachers, is undoubtedly quite worrying, the Ofsted surveys were relatively small-scale with little indication of the sampling methods used. Hence the representativeness of findings is uncertain. It is only since the undertaking of the 1996/7 round of inspections that a comprehensive picture of initial teacher education in secondary mathematics has emerged.

Whatever the case, claims of poor performance in initial teacher education courses have been used as part of the rationale for introducing a raft of measures, including the setting up of the Teacher Training Agency ${ }^{2}$ (choosing the descriptor 'training', rather than 'education'), formulating new standards for the award of qualified teacher status, a 'national teacher training curriculum', a framework for external inspection, and 'league tables' of initial teacher education providers (for evidence, see TTA press releases 19/96, 24/96, 45/97, and so on). For example, in 1996 the then Secretary of State for Education said, on taking new powers to specify the course content for trainee teachers,: "It has become increasingly obvious that newly qualified teachers, through no fault of their own, lack the teaching skills they need. I am determined this will change and these powers are a major step forward to achieving this" (DfEE press release 368/96). As Eggleston noted shortly afterwards;

\footnotetext{
${ }^{1}$ OFSTED is a non-ministerial government department established under the Education (Schools) Act 1992 to take responsibility for the inspection of all schools in England. Ofsted also has duties assigned to it in relation to the inspection of the training of teachers.

2 The Teacher Training Agency (TTA) is a statutory body set up by the Education Act 1994. It has responsibilities for teacher recruitment and initial and continuing teacher education.
} 
"teacher training is still seen as a major cause of Britain's alleged deficit in educational achievement" (Times Educational Supplement February 28 1997).

Most recently, Her Majesty's Chief Inspector of Schools has declared that there remain "key weaknesses" in courses of initial teacher 'training' such that "rigorous inspection of ITT must therefore continue so that institutions of higher education can remedy the weaknesses that remain" (Ofsted 1999a). Yet the validity and reliability of Ofsted inspection procedures have themselves been called into question (see, for example, Matthews et al 1998, and Wilcox and Gray 1996, or Centre for the Evaluation of Public Policy and Practice 1999, for accounts of school inspection). Such issues are of particular importance in initial teacher education as a poor Ofsted rating can lead to the rapid withdrawal of TTA accreditation, meaning course closure, while even satisfactory ratings can lead to uncertainty over course quota, leading to a spiral of decline in course viability.

This paper presents an analysis of the reports of Ofsted inspections of secondary mathematics PGCE courses carried out between September 1996 and July 1997. The analysis presented below shows that standards in the 21 providers inspected were judged by Ofsted inspectors to be good or better in almost three-quarters of cases. For only one course was there judged to be an issue of poor quality and this in only one aspect considered in the inspection process. This particular institution now no longer offers a secondary mathematics PGCE course, having decided to close the course following a decision by the TTA to begin the process of withdrawing accreditation (see TES 30/10/98).

In reviewing the inspection judgements, we focus on the validity and reliability of inspection process. In doing so, we should emphasise that, as the authors of this paper, we were quite satisfied with both the conduct of the inspection at our own institutions, and the outcomes. This is not partisan research. This paper is offered as a modest contribution to the process of opening the inspection of teacher education to proper academic scrutiny with a view to informing its procedures, practice, and quality. The Ofsted inspection process is not itself above critical examination.

\section{The Framework for the Inspection of Initial Teacher Education}

The "Framework for the Assessment of Quality and Standards in Initial Teacher Training 1996/7" (Ofsted and TTA 1996) was developed jointly by Ofsted and the TTA as a means of assessing the quality of initial teacher education provision in order to inform decisions on accreditation of teacher education courses and the allocation of student numbers. The framework was made up of 16 cells, with three (cells $\mathrm{C} 1, \mathrm{C} 2$, and $\mathrm{C} 3$ ) relating to the teaching competence of the student teachers being the "central assessed area" (p11). Four cells (T1, T2, T3, and T4) related to the quality of the training and assessment of students and are referred to as the major contributing area. Other contributory areas included the selection and quality of student intake (two cells, S1 and S2), the quality of staffing and learning resources (three cells, R1, R2, and R3), and management and quality assurance (four cells, M1, $\mathrm{M} 2, \mathrm{M} 3$, and M4). 
The inspection process required the observing inspector to make a judgment on a 1-4 scale for each cell. The grade 1 signifies 'very good, with several outstanding features', grade 2 'good, with no significant weaknesses', grade 3 'adequate, but requires significant improvement', and grade 4 is 'poor quality'. For each 'cell' of the inspection framework the inspection guidance gave a number of criteria against which each of these criteria has to be graded on the same 1-4 scale. For instance, cell T2 had nine criteria, an example being 'training sessions exemplify good teaching'. Once each criteria has been graded the inspection guidance indicated how the overall cell grading was to be made. For example, to receive a grade 1 for any cell, 'most criteria will be judged to be very good and none less that good. There will be only a few of the criteria judged to be good (indicative range 20\%-30\% depending on significance)'.

The sheer complexity of the framework, with its numerous criteria, some of which had 'significance', although what this meant was left undefined, led those in Higher Education Institutions to question the likely validity and reliability of the inspection process. For example, Graham advised the Autumn 1997 conference of the Universities Council for the Education of Teachers that the outcomes of the inspection using the framework "would be sufficiently unreliable to mis-represent the quality of programmes which they purport to measure, damaging the reputation of Ofsted and the institutions concerned" (Graham 1997 p 6). Issues of validity and reliability are central to this paper and so it is to those we turn next.

\section{Validity and Reliability of Inspection}

The necessity for close scrutiny of the inspection process is borne out in a number of academic publications (for instance, Graham 1997, Matthews et al 1998). Indeed, the role of Ofsted, including the validity and reliability of the inspection process, has been the subject of a comprehensive review recently completed by the Education Sub-committee of the House of Commons Select Committee on Education and Employment (House of Commons Select Committee on Education and Employment 1999).

Graham (1997 p1) claims that "the inspection process has left many HEIs [Higher Education Institutions] feeling that the quality of their provision has not been fairly judged". He argues that the methodology of the Ofsted/TTA Framework for the Assessment of Quality and Standards is unproven and reductionist, and that the "demarcations of grade boundaries have not been agreed or exemplified" (p6). It seems that Ofsted promised exemplar material for the grades (on a 1-4 scale) which has never appeared. Yet, as Gilroy and Wilcox (1997) explain, the construction of such exemplification assumes that the criteria are unambiguous and their interpretation and application straightforward. Neither, they argue, is the case. They suggest that inspectors are likely to have developed their own 'rules of thumb' which means that the scope for a wide variety of practice on the part of inspectors "would seem considerable ... thus rendering doubtful the notion of consistent and objective practice" $^{\prime \prime}(\mathrm{p} 28)$. 
This uncertainty in the inspection judgements means that there is a possibility that a course that is actually satisfactory may be awarded a grade 4, the lowest grade, which results in course closure. Tymms (1997) constructed a mathematical model to simulate thousands of inspections and calculated the likelihood of various results for different levels of security of Ofsted judgement. In particular he looked at the likelihood of a Grade 4 being given to institutions which are in fact performing satisfactorily. His calculations revealed that a satisfactory course faces a 50\% chance of being judged to be failing.

Problems of reliability and validity in the inspection process prompted Ofsted inspectors to investigate the matter. Matthews et al (1998), report on the judgements of 100 pairs of trained school inspectors who independently observed the same school lesson. Agreement occurred in $80 \%$ of cases. In $3 \%$ of cases, the judgement differed by as much as two grades. Matthews et al found "less agreement on grades .. at a sensitive area of the grading scale" (p184), the boundary between satisfactory and unsatisfactory. They also found more agreement about weaknesses than about strengths and suggest a problem with the school inspection procedure is that "inspectors take more care to record all the weaknesses .. than they do to record all the strengths". They conclude that "the anomalies here call into question the reliability of the judgments made by a very small proportion of inspectors on one occasion" (p186). Given that secondary subject courses of initial teacher education are generally carried out by a single inspector, an instance of unreliability could have devastating results. What is more, the study by Matthews et al was of "the more confident and experienced inspectors" of schools (p186). The comprehensive inspection of PGCE courses is a more recent development, with UCET claiming to have evidence of "some ill-prepared inspectors" who were "insufficiently qualified to inspect higher education provision" (UCET 1998).

\section{Methodology}

The methodological approach adopted in this study of published Ofsted reports is one of critical document analysis. As Jupp (1996 p311) explains, this involves "a critical reading of texts aimed at uncovering how problems are defined, what explanations are put forward and what is seen as the preferred solution. It also seeks to bring to the surface that which is rejected in the text and that which does not even appear: what is not seen as problematic, what explanations are not considered, and what are not preferred solutions".

The available literature noted above suggests that, in a critical analysis of the Ofsted reports, we need to look for evidence of the demarcation of grade boundaries, particularly what distinguishes one grade from another, examine the tone of reports to see whether descriptions of weaknesses outweigh expressions of course strength, and investigate the reliability of the judgments, by searching for possible inconsistencies across equal grades. 
We note that Ofsted reports are Crown Copyright and that a condition of use is that "extracts quoted are reproduced verbatim without adaptation and on condition that the source and date thereof are stated". In reporting our analysis we are conscious of the ethical issues involved in identifying individual institutions. All the extracts we reproduce below are quoted verbatim without adaptation from the 21 Ofsted inspection reports published by Ofsted as a result of the round of inspections of secondary mathematics PGCE courses carried out during 1996/7 (Ofsted 1998). Twenty of the providers inspected were partnership schemes run by HEIs; one was a school-based scheme or SCITT. All the inspections carried out in the 1996/7 round were carried out by HMI (note that this is not the case for the completing round of inspections carried out in 1997/8 when the majority of inspections were done by "additional inspectors" selected by Ofsted as being suitable for the job and given a modicum of training).

\section{Results}

The Quality of Provision

As noted above, the inspection framework (Ofsted/TTA 1996) in use for the 1996/7 round of initial teacher education inspections set out 16 'cells' that could be inspected. For the inspections undertaken, six 'cells' were selected by Ofsted and the TTA for inspection in the twenty HEI-based partnerships, whilst the one SCITT was inspected on seven cells (six of these being the same as for the HEIs inspected).

The inspected cells which were common to all twenty-one inspections are shown in Table 1, below.

Tables 1 and 2 give an overview of the inspection grades for each 'cell' inspected, source: Ofsted $1998(\mathrm{n}=21)$.

Note that grade 1 signifies 'very good, with several outstanding features', grade 2 'good, with no significant weaknesses', grade 3 'adequate, but requires significant improvement', and grade 4 is 'poor quality'.

\begin{tabular}{|c|c|c|c|c|c|}
\hline Cell & Grade & 1 & 2 & 3 & 4 \\
\hline S1 & selection procedures & $33 \%$ & $52 \%$ & $14 \%$ & 0 \\
\hline $\mathrm{T} 2$ & quality of training & $24 \%$ & $43 \%$ & $33 \%$ & 0 \\
\hline $\mathrm{T} 4$ & assessment of student teachers & $19 \%$ & $57 \%$ & $19 \%$ & $5 \%$ \\
\hline $\mathrm{C} 1$ & student teachers' subject knowledge & $33 \%$ & $57 \%$ & $10 \%$ & 0 \\
\hline $\mathrm{C} 2$ & $\begin{array}{l}\text { student teachers' planning and } \\
\text { teaching }\end{array}$ & $24 \%$ & $48 \%$ & $29 \%$ & 0 \\
\hline C3 & $\begin{array}{c}\text { student teachers' assessment of } \\
\text { pupils }\end{array}$ & $14 \%$ & $62 \%$ & $24 \%$ & 0 \\
\hline
\end{tabular}

Table 1: Grade profile of secondary mathematics PGCE courses, 1996-97 inspections $(n=21)$ 


\begin{tabular}{|c|c|c|c|}
\hline Cell & & $\begin{array}{l}\text { Percentage of } \\
\text { partnerships rated } \\
\text { 'good or better' } \\
\end{array}$ & $\begin{array}{l}\text { Percentage of } \\
\text { partnerships rated } \\
\text { 'adequate or better' }\end{array}$ \\
\hline S1 & selection procedures & 86 & 100 \\
\hline $\mathrm{T} 2$ & quality of training & 67 & 100 \\
\hline $\mathrm{T} 4$ & assessment of student teachers & 76 & 95 \\
\hline $\mathrm{C} 1$ & student teachers' subject knowledge & 90 & 100 \\
\hline $\mathrm{C} 2$ & $\begin{array}{l}\text { student teachers' planning and } \\
\text { teaching }\end{array}$ & 71 & 100 \\
\hline C3 & $\begin{array}{c}\text { student teachers' assessment of } \\
\text { pupils }\end{array}$ & 76 & 100 \\
\hline
\end{tabular}

Table 2: Profile of 'good or better' and 'satisfactory or better' by cell, 1996-97 inspections $(n=21)$

The tables above illustrate that standards in all inspected 'cells' were judged by Ofsted inspectors to be good or better in almost three-quarters of cases. This is in some contrast to the Ofsted survey some five years earlier (in 1991/2) which suggested that no secondary mathematics course were better than satisfactory (Ofsted 1993)

For only one provider was there judged to be any issue of 'non-compliance' and this in only one 'cell' from those inspected. As noted earlier, this particular course no longer operates.

Table 3, below, gives the quality of provision for courses operating in 1999/2000.

\begin{tabular}{|c|c|c|c|}
\hline Cell & & $\begin{array}{l}\text { Percentage of } \\
\text { partnerships rated } \\
\text { 'good or better' }\end{array}$ & $\begin{array}{l}\text { Percentage of } \\
\text { partnerships } \\
\text { rated 'adequate or } \\
\text { better' }\end{array}$ \\
\hline S1 & selection procedures & 89 & 100 \\
\hline $\mathrm{T} 2$ & quality of training & 78 & 100 \\
\hline $\mathrm{T} 4$ & assessment of student teachers & 83 & 100 \\
\hline $\mathrm{C} 1$ & student teachers' subject knowledge & 100 & 100 \\
\hline $\mathrm{C} 2$ & $\begin{array}{l}\text { student teachers' planning and } \\
\text { teaching }\end{array}$ & 83 & 100 \\
\hline $\mathrm{C} 3$ & $\begin{array}{l}\text { student teachers' assessment of } \\
\text { pupils }\end{array}$ & 83 & 100 \\
\hline
\end{tabular}

Table 3: Profile of 'good or better' and 'satisfactory or better' by cell, 1996-97 inspections, for secondary mathematics PGCE courses operating in 1999/2000 (n=20)

In commenting on the overall quality of secondary initial teacher training across all secondary subjects, Ofsted observes that: "the overall grade profile indicates clearly that, in the six areas assessed, the clear majority of provision is good and that the 
majority of trainees awarded QTS not only meet the standards, but do so at a good level. Some courses are of outstanding quality" (Ofsted 1999 p7). Yet the relevant Ofsted press release fails to mention this, focusing instead on what are referred to as 'shortcomings' and stating that "a significant proportion of the work inspected failed to match the aspiration that all initial teacher training (ITT) ought to be of good quality".

\section{A Critical Analysis of the Ofsted Reports}

In the data presented below, we focus mainly on cell T2 (the quality of training) both because it is a particularly important aspect of a PGCE course, and because there appears to be more variation in this cell compared to the other cells inspected. We also provide some analysis of cell C2 (the student teachers' planning and teaching).

There is a variation in emphasis given to cell T2 (the quality of training) in the reports, from three to eight paragraphs, a variation that does not appear to be related to the grade awarded for the cell. The cell is characterised in the framework for inspection by nine criteria, one of which relates explicitly to the quality of the training sessions. In only one case were the HEI-based training sessions identified as being anything other than good or very good. Despite this, six courses were judged to be grade 3 overall in cell $\mathrm{T} 2$, meaning that the course requires 'significant improvement'. Another criterion relates to students' subject knowledge. Here again there are considerable similarities between comments made on this aspect across reports from different institutions, yet the cell grades differ markedly. For example, a Grade 1 report says "There is no formal audit of students' subject knowledge after selection but the training sessions encourage students to work in groups", while a Grade 3 report says "There is no formal subject knowledge audit and the responsibility for filling gaps in subject knowledge rests with the student. This is unreliable".

Cell T2 had nine criteria in the 1996/7 framework for Inspection. Partnerships were graded on each of eight of those criteria, the ninth being 'NQTs report satisfaction with their training and there is a high level of recruitment to teaching posts'. The reason this criteria was not actually graded within cell T2 was due to lack of appropriate data as it was only in April 1996 that Ofsted began systematically collecting information on the quality of the lessons of newly qualified teachers with a view to relating this to their place of training. In contrast, four of the twenty-one reports do comment on level of recruitment to teaching posts, within cell S1 (Selection and Recruitment) even though this was not included in the framework criteria. The revised (and somewhat simplified) July 1998 Framework for the Assessment of Quality and Standards in Initial Teacher Training states that TTA data is to be used for evidence of recruitment and satisfaction from 1998/99 onwards.

Seven of the eight remaining criteria within Cell T2 were reported upon specifically in all twenty-one reports. One criteria, sub-cell ' $f$ ': 'training is differentiated to build on students' academic background and relevant experience', was explicitly mentioned in only nine of the twenty-one reports, (approximately 40\%). On closer inspection of those nine reports, in only five was the reference to differentiated training extended beyond the context of students' subject knowledge. 
For criteria T2a (concerning trainees observing and working with good teachers in their specialist subject and age-range), the Ofsted guidance document for secondary initial teacher education subject inspections 1996/97 alerts inspectors to 'full age range experience' as contextual information for reporting upon the sub-cell T2a. In six of the reports post-16 teaching was not mentioned specifically.

Overall, five providers were awarded grade 1 in cell T2. Grade 1 is listed as meaning 'very good with several outstanding features'. Further analysis of those five T2 cells reveals the results shown in Table 4 . This indicates some considerable disparity in the descriptors used to qualify evidence noted in the inspections.

\begin{tabular}{||c||c||l||c|}
\hline \hline $\begin{array}{c}\text { Institution number } \\
\text { (see appendix A) }\end{array}$ & $\begin{array}{l}\text { Number of } \\
\text { statements } \\
\text { expressing very good } \\
\text { or equivalent }\end{array}$ & $\begin{array}{l}\text { Number of features } \\
\text { listed as outstanding, } \\
\text { excellent, or } \\
\text { exemplary }\end{array}$ & $\begin{array}{l}\text { Number of "points" given } \\
\text { for consideration }\end{array}$ \\
\hline \hline 2 & 2 & 1 & 0 \\
\hline \hline 4 & 9 & 3 & 0 \\
\hline \hline 6 & 1 & 2 & 0 \\
\hline \hline 12 & 1 & 0 & 0 \\
\hline \hline 15 & 4 & 2 & 0 \\
\hline
\end{tabular}

Table 4: Analysis of reports awarding a grade 1 in cell T2 (grade 1 means "very good with several outstanding features)

Cell C2 covers the students teachers' planning, teaching and classroom management. The sections of the Ofsted reports on this cell vary in length from 223 words to 692, written in between three and eleven paragraphs; a variation that does not appear to be related to the grade awarded. Of the five reports in which five paragraphs were written on this cell, one was awarded a grade 1, three were grade 2 and one was grade 3. Given that there are 11 criteria for this cell, no particular criterion appears to be more critical than any other, as the following examples illustrate: Grade 1 course, "Students select appropriate objectives and content for most of their classes"; Grade 3 course, lesson plans "usually contain explicit objectives"; Grade 1 course: "Students taught whole classes well", Grade 3 course, "They teach whole classes well". Only one report specifically mentioned 'contributing to spiritual and moral development' and this was in the negative: "opportunities are not taken, however, to promote spiritual and moral development" (course graded a 3 on this cell).

Some reports, perhaps the most useful for course development purposes, provide examples of what the Ofsted inspector considered either good practice or an area for development. For example:

- The strength of the later training lies in the exemplification of some very effective mathematics teaching. It demonstrates how pupils can be taught to transfer their 
established knowledge, skills and understanding to different aspects of mathematics which share a common underlying structure

- School-based activities include regular meetings with subject mentors, in which students discuss their planning for the week in detail and review progress.... which allows students to discuss and evaluate the appropriateness of their teaching methods in relation to the ability of the pupils and the objectives of the lesson. Mentors provide good advice in these sessions, often showing how lessons could be introduced and developed more effectively. As a result students think more clearly about what they could add to their teaching to produce better lessons

- Mentors provide written feedback on lessons; this feedback is invariably detailed and perceptive, pointing out strengths and weaknesses...further written feedback is supplied by other mathematics teachers, the professional tutor and the university tutor, so that students acquire a range of formative assessments on their general teaching skills and in subject specific issues

- ...subject mentors organise a well-structured programme of collaborative planning and teaching, which helps students to gain confidence in managing groups and whole classes before they take full responsibility for teaching whole classes, and provides them with the opportunity to use a range of teaching methods and resources

- ....feedback was generally supportive, but either concentrated unduly on issues of classroom control and management of behaviour or was purely descriptive, and did not therefore provide sufficient challenge to prompt students' reflection

- ...students are given insufficient guidance on how to improve pupils' numeracy skills. This is the case for the taught course programme, assignments and specific training within the school and is reflected in the quality of the students' teaching

- ...students do not receive appropriate guidance in the schools when using individualised schemes

\section{Discussion}

The overall Ofsted data suggests that the overwhelming majority of courses of secondary mathematics initial teacher education courses are good or better. This is in some contrast to the earlier Ofsted survey carried out in 1991/2 which reported that no secondary mathematics course were better than satisfactory (Ofsted 1993). Either courses have improved significantly in that timeframe or there are questions over the accuracy or representativeness of the earlier finding. Certainly courses have developed over the period as provision was redesigned to ensure better partnership with the schools where trainees were placed. Such improvement, if indeed it is that rather than a more accurate reflection of course quality, is not the result of the recently developed 'initial teacher training national curriculum for secondary 
mathematics' which was only published in 1998 for full implementation by September 1999.

In terms of the validity and reliability of the inspection process, the results presented above illustrate that there is considerable variation in the lengths of the inspection reports (from 1683 to 3335 words, excluding identical preface and annex). At the level of individual cells there is also variation in the particular criteria applied and in how cell judgments are expressed. It is particularly noticeable how cell grades can differ markedly, yet statements relating to individual criteria can be virtually identical. Given the complexity of the framework for inspection (sixteen cells, specified by a series of criteria, varying in number from 4 to 11), it is impossible, given the current model of inspection report, to properly distinguish between consistency of application and the loading given to any particular criterion. The judging of cell grades is no doubt a complex matter. As Wilcox and Gray (1996 p78) comment with regard to school inspection, "we know little about how complex judgments are arrived at and even less about how inspectors actually deal with the numerous sets of criteria of which they are required to take account".

Likewise, the Education Sub-committee of the House of Commons Select Committee on Education and Employment comments that they "welcome the fact that OFSTED has undertaken research on the validity and reliability of [school] inspectors' judgements. However, we note the criticisms of this research project. It is important that there is confidence about this fundamental aspect of inspection. Full and frank research into this area must establish the level of reliability and validity of the basic elements of inspection. We wish to see research into this issue extended. It is important, to help ensure public acceptance of inspection, that such work is open to scrutiny by the academic community" (House of Commons Select Committee on Education and Employment 1999 para 129).

\section{Suggestions to improve transparency of inspections}

There are a number of ways in which the present system of inspection could be made more transparent and open to scrutiny

- Each criterion could be reported on in a specific paragraph

- The grade given for each criterion could be reported

- The mechanism for calculating the final cell grade could be made clearer (particularly, for example, the varying significance of the criteria)

- The actual evidence which resulted in particular statements being written could be recorded in the report; for example: 'the teaching seen in the HEI was exemplary because.......'

While attention to the transparency of the current inspection process appears crucial, the better reporting of inspection evidence would give specific exemplars of what Ofsted Inspectors view as good practice for each category of inspection. This could assist the identification and discussion of what can be considered as good practice in the initial education of secondary mathematics teachers.

The current inspection procedure relies heavily on the judgments of a single person, the observing inspector. A different approach to quality assurance might be to use 
evidence collected by an external assessor to help inform self-evaluation by the teacher education provider. As Graham and Barnett (1996) and Williams (1997) describe, there are different models of quality that serve different purposes. Better informed self-evaluation may lead to better new teachers more effectively that the current regime of inspection.

Courses of initial teacher education are usually inspected by single inspectors. Procedures adopted by the Teacher Training Agency mean that the awarding of a grade four in any cell leads to course closure, a grades three leads to quota uncertainty and a spiral of decline in course viability. The results of the study presented in this paper suggest that, as currently implemented, the inspection procedure may not be a completely safe way of determining course viability.

Further analysis will be made as a result of scrutiny of the inspection reports of the remaining providers of secondary mathematics initial teacher education courses which were inspected during 1997/98.

\section{References}

Centre for the Evaluation of Public Policy and Practice (1999), The OFSTED System of School Inspection: an independent evaluation. Brunel: Helix Consulting Group.

Convey, M. (Ed) 1997, The Role of Universities in the Education and Training of Teachers. London: UCET.

Gilroy, P. and Wilcox, B. (1997), OFSTED, Criteria and the Nature of Social Understanding: a Wittgensteinian critique of the practice of educational judgement. British Journal of Educational Studies. 45(1), 22-38.

Graham, J. (1997), Initial Teacher Education: TTA/Ofsted quality framework. London: UCET.

Graham, J. and Barnett, B. (1996), Models of Quality in Teacher Education. Oxford Review of Education, 22(2), 161-178.

House of Commons Select Committee on Education and Employment (1999), The Work of OFSTED: 4th report of the education and employment committee, H.C. papers 62I, session 1998-1999. London: The Stationery Office

Jupp, V. (1996), Documents and Critical Research. In R Sapsford and W Jupp (Eds), Data Collection and Analysis. London: Sage.

Lawlor, S. (1990), Teachers Mistaught: training in theories or education in subjects? London: Centre for Policy Studies.

Matthews, P., Holmes, J. R., Vickers, P. and Corporaal, B. (1998), Aspects of the Reliability and Validity of School Inspection Judgements of Teaching Quality. Educational Research and Evaluation 4(2), 167-188.

Ofsted (1992), Mathematics at Key Stages 1, 2 and 3. London: HMSO.

Ofsted (1993a), The Secondary PGCE in Universities 1991-1992. London: HMSO. 
Ofsted (1993b), The New Teacher in School: a survey by HM Inspectors in England and Wales, 1992. London: HMSO.

Ofsted (1998), Reports of the Round of Inspections of Secondary Mathematics PGCE Courses carried out during 1996/97. London: HMSO.

Ofsted (1999a), The Annual Report of Her Majesty's Chief Inspector of Schools 1997/8: standards and quality in education. London: HMSO.

Ofsted (1999b), Secondary Initial Teacher Training: secondary subject inspections 1996-98, overview report. London: HMSO.

Ofsted and TTA (1996), Framework for the Assessment of Quality and Standards in Initial Teacher Training 1996/97. London: OFSTED and TTA.

O'Keeffe, D. J. (1990), The Wayward Elite: a critique of British teacher-education. London: Adam Smith Institute.

Rannoch, Lord, (1996), Speech on the Motion: Society's Moral and Spiritual Wellbeing. Hansard, 537(120), Friday 5 July 1996.

Tymms, P. (1997), The Security of Inspection of Initial Teacher Training. Durham: University of Durham.

Universities Council for the Education of Teachers (1998), UCET Evidence to the House of Common's Select Committee Inquiry into Ofsted. London: UCET.

Wilcox, B. and Gray, J. (1996), Inspecting Schools. Buckingham: Open University Press.

Williams, A (1997), Quality Assessment in Initial teacher Education: lessons form the 1993/4 OFSTED experience. Higher Education Quarterly, 51(2), 189-200.

\section{Authors}

Keith Jones

University of Southampton

Research and Graduate School of Education

Highfield

Southampton

SO17 1BJ

tel: 02380592449

fax: 02380593556

e-mail: dkj@soton.ac.uk

\author{
Anne Sinkinson \\ Homerton College \\ University of Cambridge \\ Hills Road \\ Cambridge \\ CB2 2PH. \\ Tel: 01223313278 \\ Fax: 01223304222 \\ e-mail: ajs81@cam.ac.uk
}


Appendix A: Data on Secondary Mathematics ITE Providers inspected during 1996/7

\begin{tabular}{|c|c|c|c|c|c|c|c|c|c|c|c|c|c|c|c|c|c|c|c|c|c|}
\hline $\begin{array}{l}\text { Course } \\
\text { provider }^{3}\end{array}$ & 1 & 2 & 3 & 4 & 5 & 6 & 7 & 8 & 9 & 10 & 11 & 12 & 13 & 14 & 15 & 16 & 17 & 18 & 19 & 20 & $\begin{array}{c}21 \\
4\end{array}$ \\
\hline \multicolumn{22}{|l|}{ Cell Grades } \\
\hline S1 & 2 & 1 & 1 & 1 & 3 & 1 & 2 & 3 & 2 & 2 & 2 & 1 & 1 & 3 & 1 & 2 & 2 & 2 & 2 & 2 & 2 \\
\hline $\mathrm{T} 2$ & 2 & 1 & 2 & 1 & 3 & 1 & 2 & 3 & 2 & 2 & 3 & 1 & 2 & 2 & 1 & 3 & 3 & 2 & 3 & 2 & 3 \\
\hline T4 & 2 & 2 & 2 & 1 & 4 & 2 & 2 & 3 & 2 & 2 & 3 & 1 & 1 & 3 & 1 & 2 & 2 & 2 & 3 & 2 & 2 \\
\hline $\mathrm{C} 1$ & 2 & 1 & 2 & 1 & 3 & 2 & 2 & 2 & 2 & 1 & 3 & 1 & 1 & 2 & 1 & 2 & 2 & 2 & 2 & 1 & 2 \\
\hline $\mathrm{C} 2$ & 2 & 1 & 2 & 1 & 3 & 2 & 2 & 3 & 2 & 1 & 3 & 1 & 2 & 2 & 1 & 3 & 3 & 2 & 2 & 2 & 3 \\
\hline C3 & 2 & 1 & 2 & 2 & 3 & 1 & 2 & 3 & 3 & 1 & 3 & 2 & 2 & 2 & 2 & 3 & 2 & 2 & 2 & 2 & 2 \\
\hline $\begin{array}{l}\text { Category of } \\
\text { Provider }\end{array}$ & B & A & B & B & D & B & B & C & C & A & $\mathrm{D}$ & B & B & C & B & $\mathrm{C}$ & $\bar{C}$ & B & $\mathrm{C}$ & B & $\mathrm{C}$ \\
\hline Quota $^{6}$ & 29 & 31 & 7 & 22 & 48 & 41 & 9 & 36 & 70 & 25 & 14 & 15 & 29 & 70 & 54 & 25 & 24 & 16 & 10 & 45 & 8 \\
\hline $\begin{array}{l}\text { Number of } \\
\text { students at } \\
\text { phase two }\end{array}$ & 19 & 22 & 6 & 13 & 11 & 19 & 6 & 21 & 57 & 2 & 7 & 14 & 23 & 26 & 23 & 6 & 15 & 5 & 8 & 29 & 5 \\
\hline
\end{tabular}

\footnotetext{
${ }^{3}$ The numbers given to Course providers is arbitrary. Providers 1-20 are HEIs.in partnership arrangements with schools.

${ }_{4}^{4}$ SCITT

${ }^{5}$ As decided by the TTA on the basis of the inspection.

${ }^{6}$ As decided by the TTA.

${ }^{7}$ The number of students on the course at the time of the second part of the inspection visit when student are seen teaching.
} 